\title{
Suppression by three grass species of broom seedling emergence and survival
}

\author{
Hop Tran ${ }^{1}$, Kerry C. Harrington ${ }^{1, \star}$, Hossein Ghanizadeh ${ }^{1}$, Alastair W. Robertson ${ }^{1}$ \\ and Michael S. Watt ${ }^{2}$ \\ ${ }^{1}$ School of Agriculture and Environment, Massey University, Palmerston North, New Zealand \\ ${ }^{2}$ Scion, PO Box 29237, Christchurch, New Zealand \\ *Corresponding author: K.Harrington@massey.ac.nz
}

\begin{abstract}
Grass ground covers are often used in forestry to suppress weed germination, but little is known on how best to use grasses to suppress broom (Cytisus scoparius). In this field study, three grass species, Yorkshire fog (Holcus lanatus), Italian ryegrass (Lolium multiflorum) and perennial ryegrass (Lolium perenne), were sown at three rates in autumn and spring, then suppression of broom germination and survival of seedlings was measured. Scarified broom seeds sown at the same time as the grasses produced large numbers of competitive plants by the final assessment 12 months after sowing, regardless of the time of sowing, species of grass sown or rate of grass sown. However, no seedling emergence was recorded for the treatments in which broom seeds were sown 6 months after the grass ground cover had established. All three grass species established well, although only Yorkshire fog performed well in both seasons. Grass ground covers showed some potential to be used as part of weed management for broom in planted forests, but probably only if herbicides can also be used to control broom establishing at the same time as the grass.
\end{abstract}

Keywords broom, competition, ground cover, herbicide, weed control.

\section{INTRODUCTION}

Affordable, long-term methods of weed control are lacking for many of the world's most problematic weed species (Perry et al. 2009). Herbicides or mechanical removal can provide short-term control of invasive species but can be difficult and expensive to apply over large areas such as with forestry. Also, they usually require re-application for long-term control, and often do not promote the establishment of desirable vegetation (Sheley \& Krueger-Mangold 2003). Planting ground cover species to compete with establishing invasive weed species has been considered to be a potential approach for reducing the success of invasive species in forests (Perry et al. 2009). It has been shown that ground cover does not detrimentally affect the volume of certain tree species (Little et al. 2018).

A particularly troublesome weed species in establishing New Zealand forests is broom (Cytisus scoparius), which has dormant seeds that can remain viable in the soil for many years (Harrington 2009). In the USA, the best method found to date for managing broom has involved stimulating the abundance of associated competing vegetation (Harrington 2011). Broom is generally a shade-intolerant species (Peterson \& Prasad 1998) so over-sowing with other ground cover species is a potential option for controlling this species in newly established forests. The practice of applying herbicides to prepare a site for planting trees followed by oversowing of grasses to control weeds such as broom has been an option used in many forests within New Zealand (Richardson 1993). However, the relative competitive effects of various grass species on broom seedlings have not been studied in detail within this country. 
Hence, the aim of this study was to compare the suppression of broom seedling emergence and survival by different ground cover grass species sown at two different times of the year and at several application rates.

\section{MATERIALS AND METHODS}

\section{Study site}

Two separate experiments were conducted in a pasture with no previous history of broom populations at the Moginie Pasture and Crop Research Unit of Massey University, Palmerston North, New Zealand, from May 2008 to May 2009 (Autumn Experiment) and from November 2008 to November 2009 (Spring Experiment). Average monthly temperature and rainfall data were collected at the Grasslands AgResearch weather station approximately $1 \mathrm{~km}$ away from the study site during these experiments and are shown in Figure 1. The soil was a Tokomaru silt loam with an average $\mathrm{pH}$ of 5.2. Plant-available phosphorus $(\mathrm{P})$ was measured using the Olsen method, whereas sodium $(\mathrm{Na})$, magnesium $(\mathrm{Mg})$, potassium $(\mathrm{K})$ and calcium $(\mathrm{Ca})$ ion concentrations were determined using atomic

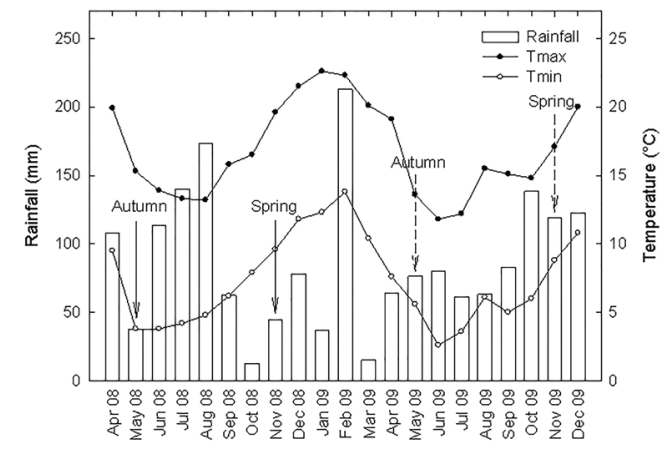

Figure 1 Mean monthly rainfall $(\mathrm{mm})$ and mean monthly maximum (Tmax) and minimum (Tmin) temperature $\left({ }^{\circ} \mathrm{C}\right)$ over the course of the two ground cover seed-sowing experiments. The solid arrows show the time when the sowing experiments were applied in autumn (12 May 2008) and spring (3 November 2008) and the dashed arrows indicate the date of termination of the experiments (after one year). absorption spectroscopy (Blakemore et al. 1987); soil organic matter was measured using a thermal conductivity detector within an Elementar Analyser ${ }^{\bullet}$ following catalytic combustion; and the cation exchange capacity (CEC) was determined using summation of the extractable cations and extractable acidity (Hesse 1971).

\section{Field experiments}

Broom seeds were collected from the soil beneath mature broom shrubs in a Eucalyptus spp. plantation at the Veterinary Large Animal Teaching Unit, Massey University. The two experiments each had a randomised block design with four replicates. The existing vegetation was cleared before each experiment, using $1.6 \mathrm{~kg}$ ai $/ \mathrm{ha}$ glyphosate (as Roundup Transorb ${ }^{\star}$ (Monsanto, Canada), a potassium salt) to kill all species present followed 2 weeks later by cultivation to form a suitable seedbed. The area was then divided into four replicate blocks each of $48 \mathrm{~m}^{2}$ $(6 \times 8 \mathrm{~m})$ with spacing between each block of $0.5 \mathrm{~m}$. Each block had one plot of $4 \mathrm{~m}^{2}(2 \times 2 \mathrm{~m})$ for each of the 12 treatments assessed (Table 1).

Three ground cover species (Yorkshire fog (Holcus lanatus), Italian ryegrass (Lolium multiflorum) and perennial ryegrass (Lolium perenne)) were assessed, each sown at three rates, referred to later as low, medium and high rates (listed in Table 1). The grass seeds were scattered by hand and raked in. The medium rate for each species equated to the rate often used by some forestry companies (Tran 2013). For each experiment, grass swards were sown just prior to sowing broom seeds; apart from the untreated control, which had no grass sown. In each plot, 44 broom seeds were then sown evenly in the centre at $15 \mathrm{~cm} \times 15 \mathrm{~cm}$ spacing using a wire grid on an aluminium frame to ensure correct spacing. Broom seeds were scarified to break dormancy just before sowing using a Forsberg scarifier for 20 seconds as this duration of scarification gave the highest rate of germination in a previous laboratory experiment (Tran 2013). No irrigation was applied, to simulate what might happen if this were a forestry site. The Autumn Experiment was sown on 12 May 2008, and the Spring 
Experiment was sown on 3 November 2008. In both experiments, an extra plot each of Yorkshire fog (Y2A; Treatment 11) and Italian ryegrass (I10A; Treatment 12) was sown in each block at the medium sowing rate but broom seeds were sown into these 6 months after sowing the grass.

The number of broom seedlings that emerged and their fate (survival or death) in each plot was recorded monthly during the first 3 months after the sowing of grasses and then monitored at 3-monthly intervals thereafter. The percentage of the ground surrounding broom plants covered by the sown ground cover species and other volunteer plant species was estimated every 3 months. At the end of the study ( 1 year) for each sowing season, all broom plants in each plot were cut at ground level, dried in an oven at $80^{\circ} \mathrm{C}$ then weighed. To quantify the botanical composition of swards surrounding the broom, three representative $50 \times 20 \mathrm{~cm}$ quadrats were randomly selected in each plot and all foliage within these quadrats was cut at ground level. The dry weight of this foliage was determined using the same method used for broom plants, though the foliage was separated into various fractions before drying, such as the main species and also dead material.

\section{Statistical analyses}

Broom data from the end of the experiment (after 1 year) were statistically analysed using SPSS software. A one-way ANOVA was used to analyse the germination, mortality and survival of broom seedlings after the normality and the homogeneity of variance of the data was checked. Where the homogeneity of variance was violated, a Kruskal-Wallis $\mathrm{H}$ test was used to analyse the data instead. Treatment effects were considered significant at $\mathrm{P}<0.05$ for all analyses.

Table 1 The treatments used in both the Autumn and Spring Experiments, with species of grass and their sowing rate. Treatments 1-10 had broom seeds sown immediately afterwards and Treatments 11-12 had broom seeds sown 6 months later.

\begin{tabular}{rllc}
\hline No. & Code & Grass species & $\begin{array}{l}\text { Sowing rate } \\
(\mathrm{kg} / \mathrm{ha})\end{array}$ \\
\hline 1 & Y1 & Yorkshire fog & 1 \\
2 & Y2 & Yorkshire fog & 2 \\
3 & Y4 & Yorkshire fog & 4 \\
4 & I5 & Italian ryegrass & 5 \\
5 & I10 & Italian ryegrass & 10 \\
6 & I20 & Italian ryegrass & 20 \\
7 & P5 & perennial ryegrass & 5 \\
8 & P10 & perennial ryegrass & 10 \\
9 & P20 & perennial ryegrass & 20 \\
10 & $\mathrm{U}$ & untreated control & not applicable \\
11 & Y2A & Yorkshire fog & 2 \\
12 & I10A & Italian ryegrass & 10 \\
\hline
\end{tabular}




\section{RESULTS}

\section{Soil composition}

Olsen-P was $43 \mu \mathrm{g} / \mathrm{mL}$ and the $\mathrm{Na}, \mathrm{Mg}, \mathrm{K}$ and $\mathrm{Ca}$ levels averaged $0.16,0.74,0.77$ and $3.2 \mathrm{me} / 100 \mathrm{~g}$, respectively. Soil organic matter averaged 5.3\% and there was an average CEC of $13 \mathrm{me} / 100 \mathrm{~g}$.

\section{Ground-cover composition}

Over the course of the study, there was a change in the species composition of swards in both experiments from a domination by annual weeds to domination by perennial weeds as shown in Figures 2 and 3. Species present in the Autumn Experiment included annual weed species: twin cress (Lepidium didymium), annual poa (Poa annua), toad rush (Juncus bufonius), prickly sow thistle (Sonchus asper), chickweed (Stellaria media), shepherd's purse (Capsella bursa-pastoris); the biennial species Scotch thistle (Cirsium vulgare); and perennial weed species: broad-leaved dock (Rumex obtusifolius) and white clover (Trifolium repens), with white clover dominating in later months (Fig. 2). Because of the domination by white clover, it was assessed separately. Species present in the Spring Experiment included the annual weed species: black nightshade (Solanum nigrum); biennial species hawksbeard (Crepis capillaris) and Scotch thistle; and perennial weed species: broad-leaved dock, white clover, hawkbit (Leontodon axatilis), dandelion (Taraxacum officinale), creeping buttercup (Ranunculus repens), narrow-leaved plantain (Plantago lanceolata) and Californian thistle (Cirsium arvense) (Fig. 3), with white clover and broad-leaved dock dominating in later months.

In the Autumn Experiment, each type of sown grass established well and initially made up a high proportion of the plants present regardless of sowing rate or species (Fig. 2a). However white clover then became very dominant, leading to a white clover/grass sward (Figs. 2bd). In the Spring Experiment, the sown grass in each treatment initially established poorly (again irrespective of application rate), mainly due to rapid establishment by black nightshade (Fig. 3a). This and other annual weeds were

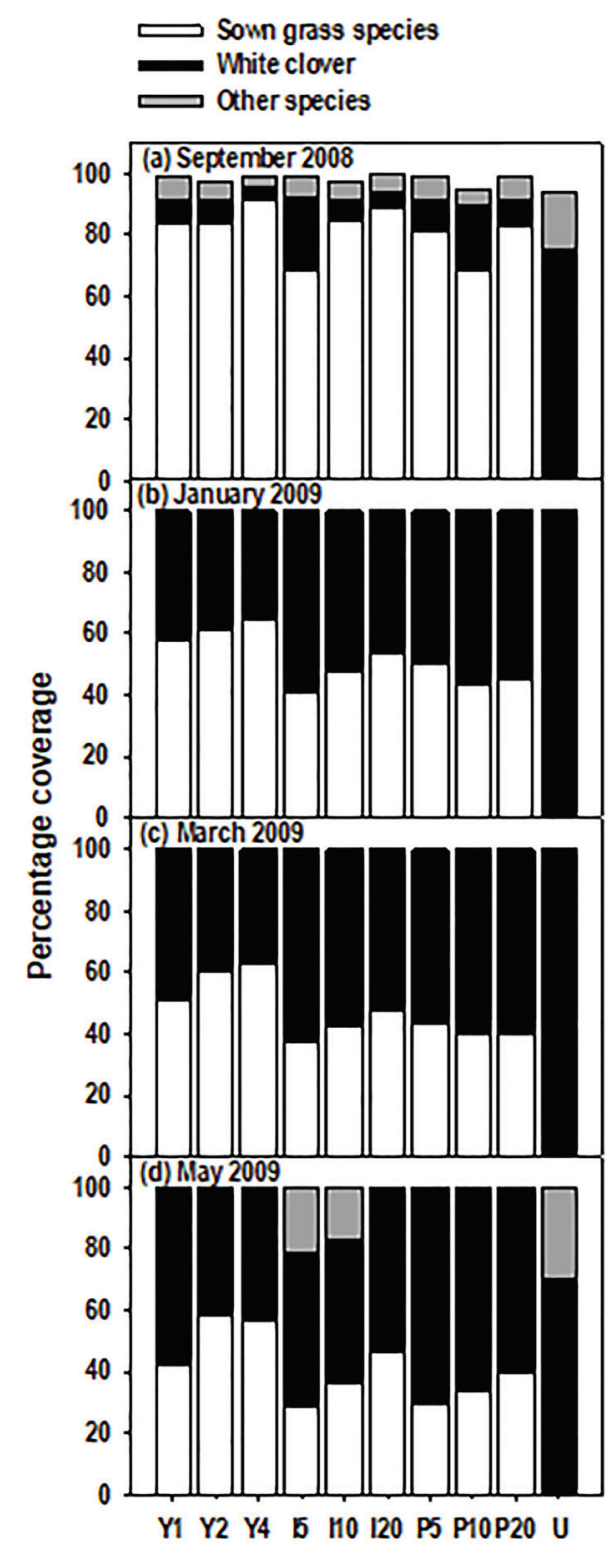

Figure 2 Mean percentage coverage in each plot by species other than broom in the Autumn Experiment: (a) 4 months; (b) 8 months; (c) 10 months; and (d) 12 months after sowing.

subsequently replaced by white clover and broadleaved dock in later months (Fig. 3d). Sown grass made up a higher proportion of the mass for the plots planted in spring compared with those in 


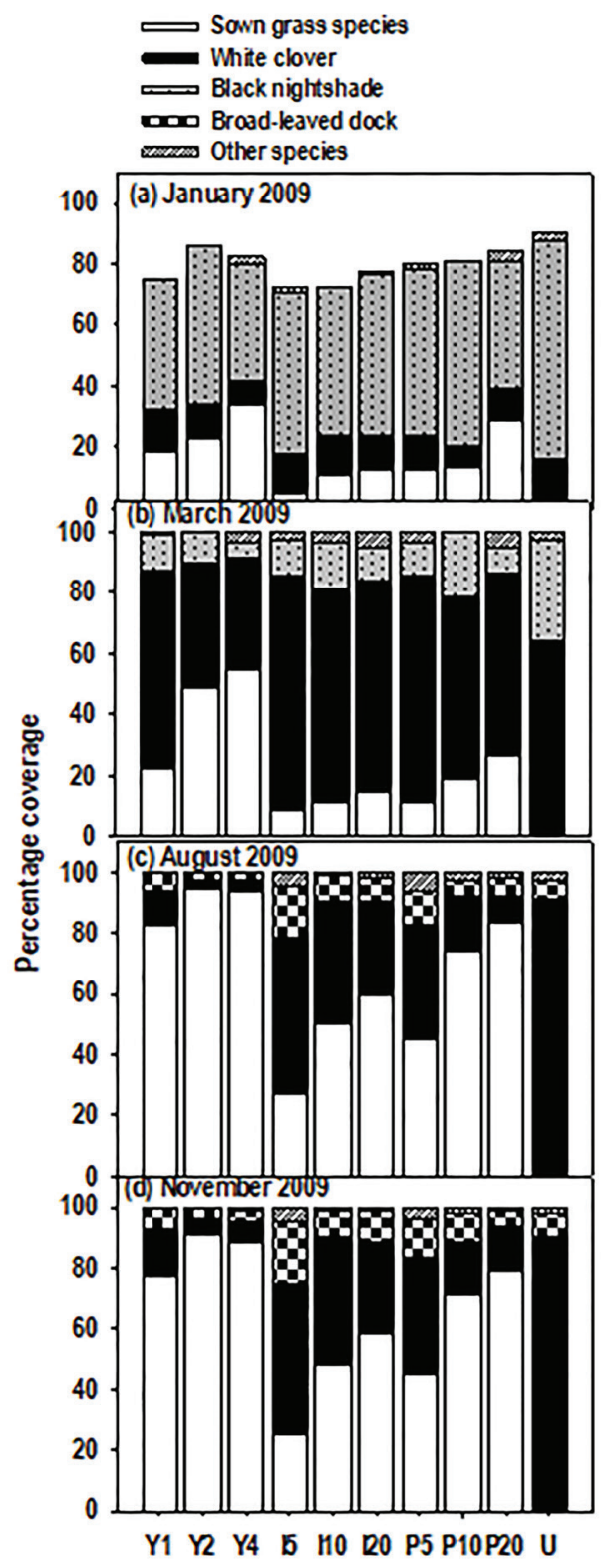

Figure 3 Mean percentage coverage in each plot by species other than broom in the Spring Experiment: (a) 2 months; (b) 4 months; (c) 9 months; and (d) 12 months after sowing.

autumn in terms of dry matter measurements made 12 months after sowing. For grasses sown in autumn, Yorkshire fog was the best performing species, with Y2 and Y3 producing 40 and $42 \%$

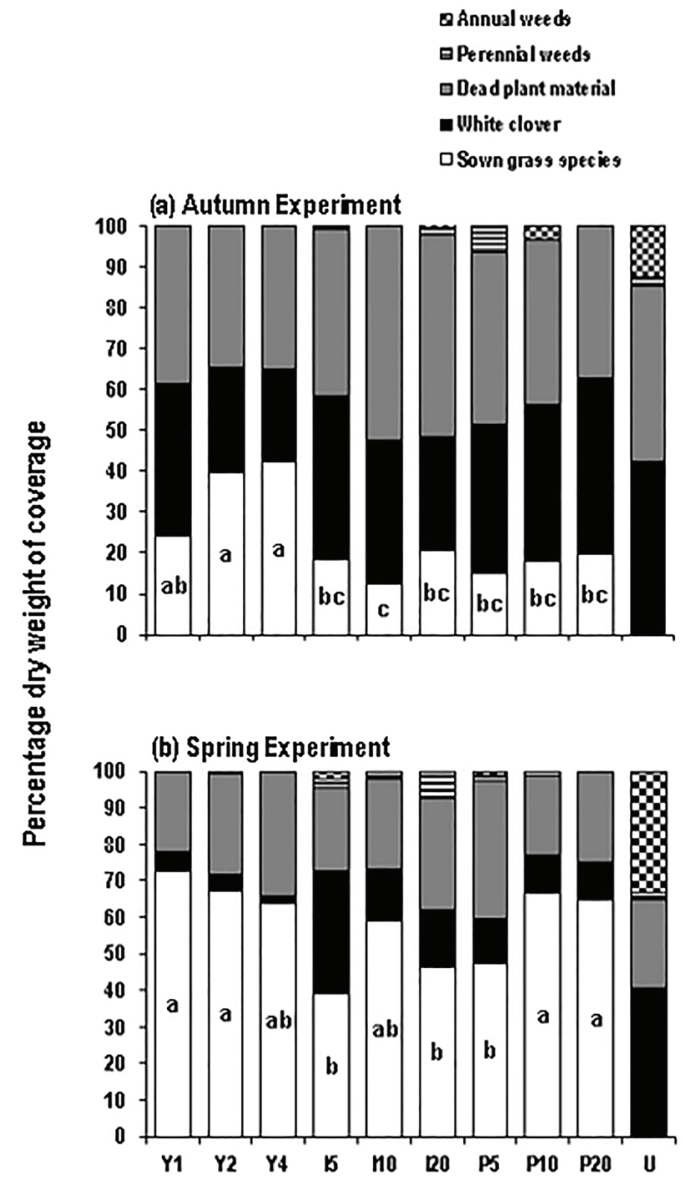

Figure 4 Mean percentage dry matter of sown grass species and other plants in: (a) the Autumn Experiment; and (b) the Spring Experiment at the end of each experiment (after 12 months). The percentage dry weight of sown grass species was statistically compared between treatments and different letters indicate significant differences between treatments, according Kruskal Wallis $\mathrm{H}$ tests for each experiment.

of the total dry matter present 12 months after sowing (Fig. 4a). The percentage of total dry matter of other grasses sown in autumn was less than $20 \%$. Sown grass species and white clover were dominant in all treatments in the spring trial but for only some treatments in the autumn trial. There was a higher percentage of annual species in the unsown plots after 12 months 
than in the treated plots in both experiments, suggesting other weeds (including broom) could still establish from seed at these latter stages of the experiment.

\section{Survival of broom}

The survival of broom seedlings in the various treatments is shown in Table 2. None of the broom seeds that were planted 6 months after sowing the Yorkshire fog (Y2A) or Italian ryegrass (I10A) resulted in seedlings that were seen during assessments. Presumably, they germinated (as they had been scarified) then died due to competition, resulting in no broom in these plots by the end of the two experiments. Another possibility is that the seeds were eaten before they could emerge, though one would have assumed at least some seeds would have escaped this fate if it was the only reason for no emergence. However, many of the broom seeds that were sown at the same time as the grass did survive, resulting in high densities of broom plants in all of the treatment plots by the end of both experiments. There were no significant differences among grass species or sowing rates in the establishment of this broom, nor was there a significant difference between plots planted with a grass and the untreated control where no grass was sown (Table 2).

In autumn, when broom seeds were sown at the same time as grass, $38-49 \%$ of the broom seeds sown with grasses had formed broom plants that were still growing strongly 12 months after sowing (appeared and survived - AAS) (Table 2). A further $27-40 \%$ of broom seeds produced seedlings that were recorded during the first

Table 2 The effect of different sowing rates of Yorkshire fog (Y), Italian ryegrass (I) and perennial ryegrass (P) in autumn and spring on the appearance and subsequent survival of broom seedlings from scarified seeds assessed 12 months after sowing. Seedlings either did not appear (DNA), appeared then died (ATD), or appeared and survived (AAS).

\begin{tabular}{|c|c|c|c|c|c|c|}
\hline \multirow{2}{*}{ Treatment* } & \multicolumn{3}{|l|}{ Autumn } & \multicolumn{3}{|l|}{ Spring } \\
\hline & DNA $\dagger$ & ATD & AAS & DNA $\dagger$ & ATD & AAS \\
\hline Y1 & $22 b$ & 40 & 38 & $59 \mathrm{~b}$ & 1 & 40 \\
\hline Y2 & $26 \mathrm{~b}$ & 32 & 43 & $59 \mathrm{~b}$ & 3 & 38 \\
\hline $\mathrm{Y} 2 \mathrm{~A}$ & $100 \mathrm{a}$ & NA & NA & $100 \mathrm{a}$ & NA & NA \\
\hline Y4 & $24 \mathrm{~b}$ & 34 & 42 & $65 b$ & 3 & 32 \\
\hline I5 & $25 b$ & 36 & 39 & $56 \mathrm{~b}$ & 2 & 42 \\
\hline $\mathrm{I} 10$ & $24 b$ & 33 & 43 & $60 \mathrm{~b}$ & 3 & 37 \\
\hline $\mathrm{I} 10 \mathrm{~A}$ & $100 \mathrm{a}$ & NA & NA & $100 \mathrm{a}$ & NA & NA \\
\hline $\mathrm{I} 20$ & $31 b$ & 27 & 42 & $61 b$ & 3 & 36 \\
\hline P5 & $23 b$ & 28 & 49 & $63 b$ & 2 & 35 \\
\hline P10 & $22 b$ & 35 & 43 & $58 b$ & 4 & 38 \\
\hline P20 & $28 \mathrm{~b}$ & 29 & 43 & $66 b$ & 3 & 31 \\
\hline $\mathrm{U}$ & $26 \mathrm{~b}$ & 24 & 50 & $66 \mathrm{~b}$ & 0 & 34 \\
\hline P value & $<0.0001$ & 0.681 & 0.711 & $0.031 \neq$ & $0.513 \neq$ & 0.997 \\
\hline
\end{tabular}

*See Table 1 for explanation of treatment codes.

$\dagger$ Different letters indicate significant differences between treatments within each column, according to Tukey's HSD tests $(\alpha=5 \%)$.

$\ddagger$ The $\mathrm{P}$ value obtained using a Kruskal Wallis $\mathrm{H}$ test.

NA - not applicable 
3 months but which subsequently died (appeared then died - ATD). The remainder of the broom seeds (22-31\%) did not produce seedlings large enough to be recorded (did not appear - DNA). For broom seeds sown with grasses in spring, 31$42 \%$ had formed aggressively growing plants by the time the experiment finished 12 months later (AAS), similar to the result from plots established in autumn (Table 2). However, $56-66 \%$ of the broom seeds never produced seedlings that were recorded (DNA), presumably due to being outcompeted by the rapid establishment of the black nightshade and other annual weeds before the first assessment (Fig. 3a).

\section{DISCUSSION}

Broom seeds usually have a hard seed coat which prevents them from germinating until this is broken. Tran (2013) recorded $86 \%$ germination of broom seeds when scarified in the same way as for this work, compared with no germination if not scarified. To have scarified these seeds prior to sowing them with the grasses may appear to have produced an advantage to the broom unlike what might occur in normal forestry oversowing. However, during site preparation in forestry, hard seed coats are likely to be broken, both by the physical action of cultivation equipment and also the bare soil that is created allowing greater heating and cooling of seeds near the surface, breaking the seed coat.

Thus, one of the main findings of this work is that broom is able to establish at least as rapidly as both grasses and weed species (such as black nightshade) to form plants that will continue to outgrow the competition around them. By the end of the experiments, broom plants were 70$80 \mathrm{~cm}$ tall in most plots, much taller than other plants around them, and a few of the plants had even begun to flower.

The other main finding is that if dormancy in the broom seeds is broken after the swards have formed (which was simulated by scarified broom sown after 6 months), the competition is much too severe to allow the broom to establish. This confirms other work in which broom seedlings have been shown to be poor competitors for light if germinating into a competitive environment (Hosking et al. 1996).

In recent work, Tran et al. (2016) have shown that several herbicide treatments (such as a clopyralid/triclopyr mixture) can be applied selectively over young pines and grasses to kill broom plants that are less than 12 months old. It would only be economically feasible to apply such herbicide treatments once during the establishment phase of a forest, so it is important that no further broom establishment occurs after this first spraying.

The high incidence of weeds in the treated plots could be viewed as a reason for not sowing grass as ground cover during forest establishment. However, a clopyralid/triclopyr mixture would kill most of these other species (including the white clover) as well as the broom. This mixture would have also allowed the grasses to dominate more than they did. Despite lack of selective herbicide, all three grass species did establish quite well, though Yorkshire fog was the most dominant species for the treatments sown in autumn.

The unusually high amount of rainfall in February 2009 (Fig. 1) may have resulted in better grass establishment for the spring-sown seeds than might normally have occurred had there been a dry summer within the first 6 months of sowing the grasses in November. The sowing rate of grass species had no effect on the survival of broom seedlings. However, the growing conditions in the cultivated seedbed used for this trial may have allowed better establishment of grass seeds than if seeds had been sown by aerial topdressing onto the sites traditionally used for planting pines.

The plant species that established as weeds around the grasses and broom would vary from site to site depending on the history of each site and thus the seed bank in the soil. As the site of this trial had been in pasture for many years, it could be considered not typical of a forestry site. However, presumably most sites would have a range of annual and perennial weed species in the seed bank, so competition with both the broom and the grasses would always be likely to occur 
from whatever species are present. Applying a clopyralid/picloram mixture would help control many species in addition to broom during the establishment phase to encourage the formation of a grass sward around the trees for competition with future germinating broom seeds.

It is well known that broom can have large negative effects on growth of newly planted Pinus radiata (radiata pine) (Richardson et al. 1997; Richardson et al. 1999) and it can also have a strong influence on tree growth when it is present as an understorey species in much older pine stands (Richardson \& Whitehead 2002). The establishment of broom seedlings is the most important life history transition affecting radiata pine establishment and growth (Parker 2001). Therefore, controlling broom during this stage is extremely important for reducing future invasions into forests. The results of the current study have indicated that grass ground covers have good potential to be used to prevent broom from establishing, but only if used in conjunction with herbicides as part of an Integrated Weed Management (IWM) approach to managing broom seedlings in planted radiata pine forests. Field trials involving ground cover establishment in combination with application of selective herbicides are needed at forest sites, however, to provide more information on how effectively broom can be controlled using grass ground covers.

\section{ACKNOWLEDGEMENTS}

We wish to thank the former Foundation for Research, Science and Technology (FoRST) and New Zealand's International Aid and Development Agency (NZAID) for financial assistance, Grasslands AgResearch for providing weather data, Lance Currie for soil analysis, and also Mark Osborne and Ruth Morrison for technical assistance.

\section{REFERENCES}

Blakemore LC, Searle PL, Daly BK 1987. Methods for chemical analysis of soils. New Zealand Soil Bureau Scientific Report 80. 103 p.
Harrington TB 2009. Seed germination and seedling emergence of Scotch broom (Cytisus scoparius). Weed Science 57(6): 620-626.

Harrington TB 2011. Quantifying competitive ability of perennial grasses to inhibit Scotch broom. Research Paper PNWRP-587. Portland, OR: U.S. Department of Agriculture, Forest Service, Pacific Northwest Research Station. 15 p.

Hesse PR 1971. A textbook of soil chemical analysis. John Murray, London. 520 p.

Hosking JR, Smith JMB, Sheppard AW 1996. The biology of Australian weeds 28. Cytisus scoparius (L) Link subsp. scoparius. Plant Protection Quarterly 11(3): 102-108.

Little KM, Rolando CA, Morris, AR 2018. Impacts of under-canopy vegetation on stand growth in two pine saw-timber stands, South Africa. New Zealand Journal of Forestry Science 48:2.

Parker IM 2001. Safe site and seed limitation in Cytisus scoparius (Scotch broom): invasibility, disturbance, and the role of cryptogams in a glacial outwash prairie. Biological Invasions 3(4): 323-332.

Perry LG, Cronin SA, Paschke MW 2009. Native cover crops suppress exotic annuals and favor native perennials in a greenhouse competition experiment. Plant Ecology 204(2): 247-259.

Peterson DJ, Prasad R 1998. The biology of Canadian weeds. 109. Cytisus scoparius (L.) Link. Canadian Journal of Plant Science 78(3): 497-504.

Richardson B 1993. Vegetation management practices in plantation forests of Australia and New Zealand. Canadian Journal of Forest Research 23(10): 1989-2005.

Richardson B, Vanner A, Ray J, Balneaves J 1997. Effect of some common weed species on Pinus radiata growth at a dry South Island site. Proceedings of the New Zealand Plant Protection Conference 50: 373-376.

Richardson B, Kimberley MO, Ray JW, Coker GW 1999. Indices of interspecific plant competition for Pinus radiata in central north island of New Zealand. Canadian Journal of Forest Research 29: 898-905. 
Richardson B, Whitehead D 2002. Root-zone water storage and growth of Pinus radiata in the presence of a broom understorey. New Zealand Journal of Forestry Science 32(2): 208-220.

Sheley RL, Krueger-Mangold J 2003. Principles for restoring invasive plant-infested rangeland. Weed Science 51(2): 260-265.

Tran H 2013. The ecology and integrated management of broom (Cytisus scoparius) in New Zealand plantation forests. PhD thesis, Massey University, Palmerston North, New Zealand. http://hdl.handle.net/10179/5468.

Tran H, Harrington KC, Robertson AW, Watt MS 2016. Assessment of herbicides for selectively controlling broom (Cytisus scoparius) growing with radiata pine (Pinus radiata) in New Zealand. New Zealand Journal of Forestry Science 46:13. 